Anna WitKowsKa-PaLeń

University of Rzeszów, Poland

\title{
PROBLEMS EXPERIENCED BY FAMILIES OF PRISONERS AND POSSIBILITY OF SOCIAL ASSISTANCE AND SUPPORT
}

\begin{abstract}
The purpose of the paper is to show the difficulties experienced by the families of persons serving prison sentences, as well as to analyse the possibilities of social assistance and support for families of prisoners in overcoming these problems. This paper is a review of scientific literature and legal documents and shows the scope of assistance provided to prisoners and their families. Families of prisoners are often the subject of research because of their role in the process of rehabilitation and social reintegration of prisoners. Families themselves, however, and especially the problems they experience with the imprisonment of a family member, receive little attention. Families of people committing criminal acts are often dysfunctional families that are struggling with numerous social, emotional, and legal problems, and imprisonment of a family member further intensifies these problems. The analysis carried out in this paper shows that there is a lack of forms of assistance directed specifically to the families of prisoners, and if these families do benefit from the assistance of public institutions, they do so mainly indirectly, through the assistance provided to prisoners and through post-penitentiary assistance in the process of adaptation to life after release from prison.
\end{abstract}

KEYWORDS: families of prisoners, family dysfunctions, social exclusion, social support, post-penitentiary assistance 


\section{INTRODUCTION}

Families of persons serving prison sentences receive a great deal of attention in the scientific literature, but mainly in terms of their role in the process of the rehabilitation and social reintegration of prisoners. The literature on this subject emphasizes that the family environments of convicts constitute a kind of social capital for them, as they are the most important and, in some cases, only source of support and contact with the outside world. It is noted that families of prisoners meet their social and emotional needs which, in conditions of prison isolation, are highly deficient, as well as provide them with material support and the encouragement to abandon criminal lifestyles and to adopt legal behaviour (more information can be found in Mills, Cood, 2008; Machel, 2014; Wolińska 2016). On the other hand, the families themselves, especially the difficulties they experience when their members are imprisoned, are rarely the subject of scientific considerations. It is often forgotten that the "costs" of imprisonment are borne not only by the convicts themselves, but also by their entire families (spouses and children), and a court sentence is a punishment not only for the convicts, but also for his or her relatives who become "unintentional" victims of the justice system (Light, Campbell, 2007, p. 298; Pindel, 2011, p. 98).

Scientists studying this subject matter, by focusing almost exclusively on the role of the family in the process of the rehabilitation of the prisoner, assume that there are only "healthy" family systems that are able to overcome on their own the numerous social and emotional problems associated with imprisonment of family members, while at the same time creating a valuable source of support for the prisoner. However, families of prisoners are often dysfunctional environments, and they struggle for years with various problems of a financial, emotional, or social nature, and the situation of penitentiary isolation of a family member further intensifies these problems (Barczykowska, 2008, p. 341; Deka, 2017, p. 193).

Considering the above, the intention of the author of this paper is to present the difficulties experienced by families when their member is imprisoned and to show the forms of social assistance and support available to them in overcoming these problems. 


\section{DIFFICULTIES EXPERIENCED WHEN A FAMILY MEMBER IS IMPRISONED}

The problems experienced by families with members in prison are varied and often complex. Imprisonment of a family member - even though the situation is rarely sudden and unexpected, as it is preceded by a court case - becomes a crisis situation in the life of the entire family. Conviction and imprisonment of a family member results in complete disorganization of family life and involves strong negative emotions felt by the rest of the household. This becomes a source of stress, frustration, regret, anger, and a feeling of loss. In the literature on this subject, a lot of attention is paid to various crisis situations in the lives of individuals and families and ways to counteract them; the most common examples of such situations that are given are death of a relative or friend, divorce, long-term and serious illness, disability, loss of a job, poverty, natural disaster, homelessness, and domestic violence (see Otwinowski, 2010, p. 86; Nowak, 2011, pp. 162-163). Imprisonment of a family member is rarely analysed in terms of a crisis situation in the family and only a few authors perceive this situation as atraumatic breakthrough that exacerbates intra-family problems" (Barczykowska, 2008, p. 344), an "acute emotional breakdown," or even a "family stress syndrome" experienced by family members (Machel, 2014, p. 48). However, detention of a family member, like any other crisis situation, gives rise to a sense of threat and uncertainty as to the future, due to a dramatic change in stable life and a need to change the existing ways in which a family functions (cf. Włodarczyk, 2011, p. 315). Moreover, unresolved emotional problems associated with imprisonment of a family member can lead to a reduced sense of agency and self-confidence, and a loss of adaptability and control over one's own life, which causes further emotional problems and crises in the family (cf. Kubacka-Jasiecka, 2016, p. 55).

Detention of a family member also means for the other members of his or her household, mainly the convicted person's spouse or partner, regular and often long-term contact with the penitentiary institution and its procedures. One should also keep in mind that this is a contact with a "total institution," i.e. one in which "entire groups of people are treated in a bureaucratic manner and, at the same time, are physically isolated from the normal course of life 
activities" (Goffman, 2006, p. 316). The prison, as a total institution, seeks to subordinate the entire life of the inmates to an internal, strictly defined discipline and to rigors imposed by its staff, while limiting their contacts with the outside world. This separate and unique social world, based on coercion and absolute obedience, has an enormous impact not only on the prisoners (their attitudes and behavior) but also on their family members who wish to maintain contacts with the prisoners.

Family members (e.g. prisoners' wives) often spend long hours waiting for a visit in a prison or for a phone call from the imprisoned partner at times strictly defined in the prison regulations. They are also subject to strict supervision and control by the prison staff when visiting the prison, and to certain requirements when writing letters and preparing parcels for the prisoner. Over time, this causes the rhythm of prison life, defined by the penitentiary procedures and rules, to gradually infiltrate the daily life of the family, and the partners of prisoners are forced to constantly modify their personal and professional plans in order to adapt them to the schedule of visits at the penitentiary. Contact with the penitentiary institution also causes them to gradually change their image and style of dress to comply with prison regulations, and even to learn a unique prison jargon. This is a phenomenon which in the literature on this subject matter is referred to as secondarily prisonised (Comfort, 2008, pp. 28-30).

Being secondarily prisonised, defined as a process of adaptation and submission to the rigors of prison life by members of a prisoner's family, in practice means a kind of restriction of their freedom, and their contacts with the prison system are marked by various kinds of negative feelings, such as a sense of shame and humiliation, helplessness, distrust, a sense of being lost or losing control over their own life. Being secondarily prisonised may also lead to a drop in confidence in the institutions of the justice system (or, more broadly, public institutions) and contribute to social marginalization of the family and its exclusion from social life (Szczepanik, Miszewski, 2016, pp. 61-62; Bębas, 2017, p. 119).

Marginalization and social exclusion of prisoners' families are also fostered by stigmatization of such families in the social environment. The stigma of a "degenerate" or "criminal" is borne not only by the inmate, but 
often also by the members of his or her family, causing their isolation and social degradation.

According to Erving Goffman's concept, any person who somehow stands out in a social environment, either because of his or her physical characteristics (e.g. various disabilities) or because of certain events and life situations (e.g. conviction and imprisonment), can be defined as, and marked with the stigma of, a "degenerate." Such a stigma causes members of the society not only to "move away' from the stigmatized individual, but also to apply various forms of discrimination against him or her. What is more, the status of a degenerate causes the people stigmatized by the society to develop a negative image of themselves and to make various attempts to adapt to the situation (Goffman, 2005, pp. 35-37).

People who have entered into conflict with the law and have been imprisoned are particularly vulnerable to stigmatization. The stigma of a "criminal" makes these people experience isolation and social exclusion after they are released from prison (e.g., they have problems with finding jobs and renewing their former social contacts). But their family members also experience stigmatization and the associated social ostracism, e.g. in their neighborhoods or schools (Paszkiewicz, 2017, pp. 55-56).

Prisoner families, often stigmatized as "families of criminals," are seen as "not entirely blameless," if not "accomplices," and as such are thought to deserve social condemnation. In the public opinion, women who became spouses or partners of "criminals" "deserve" their difficult fate after the imprisonment of their partner, while children of convicts are often perceived as potential deviant individuals (according to the proverb, "like father, like son"). Prisoners' families experiencing social ostracism cannot count on help and support from their closest social circle (neighbours, friends, farther relatives), while at the same time isolating themselves from social contacts, trying to hide as long as possible the imprisonment of a family member (Fidelus, 2016, p. 336; Deka, 2017, p. 195; Kieszkowska, 2018, p. 169).

Families of persons serving prison sentences also often experience financial problems. In general, the financial situation of convicts (even before their imprisonment) and their families is quite often the subject of various 
scientific studies and analyses, which usually prove that these families are in a bad financial condition and their socio-professional status is low. This situation is caused by many factors. The most important ones are low level of education and lack of professional qualifications of both convicts and their partners, unemployment and occupational inactivity (and often also learned helplessness), which lead to a criminal lifestyle, tendency to become addicted, etc. As a result of these factors, families of convicts are quite often unemployed and make a living working in low-paid jobs, performing casual work, or receiving social benefits. However, imprisonment of a family member additionally deepens this difficult financial situation in the family (Szymanowska, 2003, pp. 29-30, 111; Barczykowska, 2008, p. 348; Kacprzak, Kudlińska, 2014, pp. 44-46; Kieszkowska, 2018, pp. 172-173). Families where the prisoner was the main or sole breadwinner are particularly vulnerable. In this case, the partner of a convict, who has not been imprisoned, must accept the role of a breadwinner and also bear the costs of visits at the prison, telephone calls with the prisoner, and preparing parcels with food for or giving money to the prisoner (Barczykowska, 2008, p. 349; Szczepanik, Miszewski, 2016, p. 64; Fidelus, 2016, p. 336).

The disorganization of family life linked to a family member's prison sentence also adversely affects the situation of underage children. Imprisonment of one parent results in a type of temporarily incomplete family in which the entire burden of care and upbringing of the children and securing their financial well-being rests on the shoulders of the other parent. The parent who is left alone (most often the mother), unable to cope with the difficulties of everyday life and additionally experiencing strong emotions associated with the imprisonment of their partner, may neglect the children and their needs. In such families, therefore, dysfunctions in the upbringing process are often observed, because single mothers "are guided by moods, are irresponsible, harsh, unfair, and apply unfair and harsh disciplinary measures" towards children (Fidelus, 2016, p. 337). A parent's imprisonment also poses a threat to proper emotional and social development of underage children. As various studies have shown, children of prisoners often exhibit emotional disorders (anxiety, sleep disorders, low self-esteem, lack of sense of meaning of life, neurosis, depression, etc.), and, moreover, due to the 
shortcomings in their upbringing, may also exhibit symptoms of social maladjustment. Thus, they often exhibit behavioural problems at home and at school, neglect school duties, play truant, tend to be aggressive, use intoxicants and narcotics, become members of dysfunctional peer groups, and commit punishable acts (Barczykowska, 2008, p. 346; Domżalska, 2011, pp. 218-219; Oldrup, Frederiksen, 2018, pp. 108-110).

What may also be difficult for the family is the return of the convict to the family environment after serving his or her prison sentence. A family member's stay in prison, especially for many years, poses a threat to the sustainability of family relationships, both marital and parental. Prison isolation limits prisoners' participation in the daily lives of their families and in important events (holidays, children's birthdays, family celebrations, etc.) and makes family members increasingly emotionally distant from each other. Therefore, various authors emphasize that, as a consequence of a family member's stay in prison, the emotional bond with his or her spouse and children may weaken or even completely break (Domżalska, 2011, pp. 218-219; Machel, 2014, p. 51; Szarzała, 2016, p. 315; Kieszkowska, 2018, p. 171). Of course, the weakening or even complete disintegration of family ties is not always the result of a convict's stay in prison; severance of a family's contacts with the prisoner is often a consequence of the lifestyle that the latter had led prior to his or her imprisonment (e.g. alcohol abuse and domestic violence) and of the conflicts within the family (cf. Szczepanik, Miszewski, 2016). It would seem that in this situation penitentiary isolation brings stability, "relief" and some peace to the family (cf. Barczykowska, 2008, p. 343), but one should keep in mind that imprisonment of a family member does not resolve the conflict, but rather contributes to its "exacerbation" when mutual resentment, accusations, and feelings of guilt arise in relation to the imprisonment of a family member. It would also seem that only families with conflicts and disturbed family bonds experience the emotional difficulties associated with family members returning from prison. However, even in families where there are no significant conflicts, the return of a family member after years of imprisonment can also become a difficult situation (sometimes even a crisis) when family life has to be reorganized again (cf. Deka, 2017, p. 196; Iwanowska, 2013, p. 33). This is especially true when 
family members are emotionally distant from each other and when the family has achieved relative stability in life and has learned to function in a changed family composition.

\section{THE SCOPE OF ASSISTANCE AND AVAILABLE FORMS OF SUPPORT}

Generally speaking, the system of social assistance and support lacks specific forms of assistance to families whose members are serving a prison sentence. In principle, the only form of assistance dedicated to such families is ad hoc material support from the Justice Fund (Journal of Laws 2019.683). It is available to the families of prisoners who are in a difficult financial situation, especially where the prisoner had been the main or sole breadwinner. The family may apply for this form of assistance by submitting an application to the professional probation officer responsible for the family member in question. However, such assistance is available to prisoners' families for a relatively short period of up to 3 months after the date of the family member's imprisonment, with the possibility of extending it to 6 months in exceptional circumstances such as illness or temporary incapacity of the prisoner's partner to work (see sec. 40.5 and sec. 41.3).

Prisoners' families that experience various life problems can of course apply for social welfare benefits. Such families, as well as any families in a difficult life situation, are entitled to a whole spectrum of benefits, both tangible and intangible, provided that they meet the detailed criteria specified in the Act on social assistance. Thus, due to various difficulties of a financial, social, or emotional nature or in connection with problems concerning care and education, a family may apply for assistance, e.g. in the form of a periodic allowance or a special purpose allowance, as well as in-kind assistance, specialized counselling (including legal, family, and psychological), social work, crisis intervention, etc. (more information can be found in Article 36 of the Social Assistance Act). It should be emphasized, however, that the statutory reasons for granting social assistance do not include any separate situations involving penitentiary isolation of a family member (e.g. spouse or parent) as grounds for granting social assistance. Therefore, families of 
persons serving a prison sentence may apply for social assistance for "other" reasons, such as poverty, homelessness, unemployment, disability, chronic or serious illness, helplessness with respect to matters concerning care and education, etc. (see Article 7 of the Social Assistance Act).

On the other hand, the Act on social assistance clearly distinguishes the criterion of "difficulties in adapting to life after release from prison" in the case of persons leaving penitentiary institutions (Article 7(12)). Even if the current model of social work assumes focusing not so much on the individual as on the entire family (the so-called systemic approach to working with the family - more information can be found in Kadela, Kowalczyk, 2014, pp. 52-52), it is aimed at overcoming the adaptation difficulties experienced by former prisoners. It is the prisoner who remains the main beneficiary of the aid and his or her family plays a secondary role. Moreover, even if one assumes that social work in this area is focused on supporting not only the former prisoner but the whole family in solving the problems and difficulties they experience in their lives, it is still an ex post assistance, because it starts not when a family member is put in prison, but only when he or she is released from prison (cf. Fidelus, 2016, p. 339).

Another indirect form of support for families of people serving prison sentences and released from prison is all actions taken by the Prison Service and probation services (court probation officers) as a part of their penitentiary work and post-penitentiary assistance for convicts. As provided for in Article 67(3) of the Executive Penal Code (Journal of Laws 2020.523), one of the most important means of influencing prisoners is the possibility for them to maintain "contact with the family and the outside world;" therefore, prison staff are actively involved in activities aimed at helping prisoners to maintain, strengthen, or rebuild family ties. In addition to visits of relatives, letters, telephone calls, or contacts through other means of communication (see Article 105(1)), regular meetings are also organized in prisons with members of prisoners' families (for example during holidays, Father's Day, Mother's Day, etc.). Penitentiary institutions also implement a number of social reintegration programs aimed to support families, which enable prisoners to acquire skills and competences useful in family life, including building positive marital and parental relations (see Witkowska-Paleń, 2015, pp. 180-182). 
As a part of their preparations for prison releases, probation officers also take various actions, including those related to the families. The role of the probation officer who is working on the prisoner's release program is to establish contacts with the prisoner's family in order to identify their family and community situation, and to prepare this community for the prisoner's return from prison and organize post-penitentiary support on the basis of the identified needs of the prisoner and his or her family, in cooperation with various bodies and institutions that support social reintegration of prisoners (see sec. 41 of the Regulation of the Minister of Justice of 13 June 2016).

However, the above-mentioned activities, which are invaluable, are not intended directly for the families of persons serving prison sentences and those released from prison, and the families become the beneficiaries of this type of support only indirectly, as a result of the assistance provided to prisoners and former convicts. Not only public forms of assistance addressed directly to the families of prisoners, but also institutions that would carry out such tasks are lacking. This gap is partly filled by NGOs.

The "Help for Those in Need" Foundation in Warsaw provides assistance to families of incarcerated persons. Its range of assistance includes financial and in-kind assistance (e.g. purchase of food products and needed clothing, and co-financing of utilities and rent), as well as educational support for children, family mediation, and assistance in finding work for unemployed family members of prisoners. The foundation also provides legal and administrative support to families of prisoners and organizes workshops on conflict resolution and overcoming aggressive behaviour for family members of convicts (https://www.pomoc-potrzebujacym.pl/index.php/pomoc-iformy-wsparcia/dla-rodzin-osob-osadzonych).

The Małopolska Probation Association, based in Krakow, also works to improve the situation of prisoners' families, especially their underage children. This organization works with families of convicts in their local communities, providing them with social, psychological, and therapeutic assistance, as well as providing assistance in finding work and vocational guidance (http://probacja.org/opieka-postpenitencjarna-i-wsparcie-dla-rodzinosadzonych/). It is also actively involved in activities aimed at preventing stigmatization of prisoners' children and, since 2018, has participated in the 
international social campaign Not my crime, still my sentence, carried out by the European network of organizations "Children of Prisoners Europe". (http://probacja.org/2018-not-my-crime-still-my-sentence/).

The Sławek Foundation, based in Warsaw, is also involved in helping the families of prisoners. It organizes support groups for people whose relatives are in prisons. Members of such groups provide each other with mutual help by sharing their experiences related to imprisonment of a family member and information on the possibility of obtaining support in solving their life problems and difficulties (https://www.fundacjaslawek.org/wsparciedla-rodzin). Participation in groups of this kind has a therapeutic value for families of prisoners as it gives them the opportunity to share, in an atmosphere of trust and acceptance, their difficult experiences and emotions connected with the imprisonment of a family member. Another key aspect of self-help groups is the fact that they are a place for establishing contacts and social relations that underlie social capital, which is so important in the case of families of prisoners that experience marginalization and exclusion in their communities (cf. Szczepanik, Miszewski, 2016, pp. 63-64).

\section{Conclusions}

Isolation in prison becomes a source of a variety of emotional, social, financial, and legal problems for family members of the prisoner. When a family member is imprisoned, his or her relatives experience a number of negative emotions (e.g. regret, anger, frustration, and feeling of loss) which may lead to an emotional crisis, making it difficult to adapt in a changed family situation. Imprisonment also involves certain procedures and prison rules, which must be complied with not only by the convict, but also by his family and friends who wish to maintain regular contact with the prisoner. This makes imprisonment a severe "punishment" not only for the convict, but also for his or her entire family. Imprisonment of a family member (e.g. father, husband, or partner) also often involves financial problems, especially when the convict had been the main or sole breadwinner for the family, which leads to a disruption in the upbringing of minors and stigmatization of the family in the local community. 
Families of prisoners that experience such problems are clearly alone when it comes to social assistance and support from public institutions. While many different forms of assistance provided by the Prison Service, probation services, or social assistance institutions are intended for prisoners and persons released from prison, there is a deficit in such assistance for the families of imprisoned persons, and if such assistance is provided, it is mainly indirectly, through the support provided to the prisoners themselves or through post-penitentiary assistance.

\section{References}

Barczykowska, A. (2008). Sytuacja życiowa rodzin osób pozbawionych wolności. w: L. Golińska, B. Dudek (red.), Rodzina i praca z perspektywy wyzwań i zagrożeń (ss. 341-352). Łódź: Wydawnictwo UŁ. ISBN 9788375251876.

Bębas, S. (2017). Skutki uwięzienia członka rodziny i znaczenie rodziny dla więziennego funkcjonowania osadzonych oraz ich resocjalizacji i readaptacji. Ruch Pedagogiczny 4, ss. 115-127. ISSN 0483-4992.

Comfort, M. (2008). Doing Time Together. Love an Family in the Shadow of the Prison. Chicago, IL: University of Chicago Press. ISBN 0226114635.

Deka, R. (2017). Rodzina w sytuacji odosobnienia jednego z jej członków. Izolacja więzienna jako zagrożenie dla prawidłowego funkcjonowania rodziny. w: B. Szluz, A. Szluz, M. Urbańska (red.), Współczesna rodzina. Aspekty społeczno-prawne (ss. 191-200). Rzeszów: Wydawnictwo UR. ISBN 9788379964574.

Domżalska, A. (2011). Dzieci rodziców pobawionych wolności. Forum Pedagogiczne 1, ss. 215-224. ISSN 2083-6325.

Fidelus, A. (2016). Praca na rzecz rodziny doświadczającej problemów związanych zizolacja więzienna jednego z jej członków. w: T. Biernat, K. Kuziak, J.A. Malinowski (red.), Rodzina w pracy socjalnej - pomoc w sytuacjach trudnych i kryzysowych (ss. 331-343). Toruń: Wydawnictwo Edukacyjne „Akapit”. ISBN 9788363955359.

Goffman, E. (2005). Piętno. Rozważania o zranionej tożsamości. Przeł. A. Dzierżyńska, J. Tokarska-Bakir. Gdańsk: GWP. ISBN 9788374890472.

Goffman, E. (2006). Charakterystyka instytucji totalnych. w: A. Jasińska-Kania, L.M. Nijakowski, J. Szacki, M. Ziółkowski (red.), Współczesne teorie socjologiczne (ss. 316-335). Tom I. Warszawa: Wydawnictwo Naukowe Scholar. ISBN 9788373832213.

Iwanowska, A. (2013). Przygotowanie skazanych do życia na wolności w trybie art. 164 k.k.w. Warszawa: Wyd. Biuro Rzecznika Praw Obywatelskich. ISBN 9788393836611 . 
Kacprzak, A., Kudlińska, I. (2014). Praca socjalna z osobami opuszczajacymi placówki resocjalizacyjne i ich rodzinami. Warszawa: Centrum Rozwoju Zasobów Ludzkich. ISBN 9788379513123.

Kadela, K., Kowalczyk, J. (2014). Standardy pracy socjalnej. Rekomendacje metodyczne i organizacyjne. Warszawa: WRZOS. ISBN 9788393956531.

Kieszkowska, A. (2018). Rodziny uwięzionych $i$ ich miejsce w środowisku lokalnym. Acta Scientifica Academiae Ostroviensis 11 (1), ss. 168-188. ISSN 2300-1739.

Kubacka-Jasiecka, D. (2016). Kryzys emocjonalny i trauma szansa na rozwój i potęgowanie zdrowia. Watpliwości i pytania. Rocznik Filozoficzny Ignatianum 22 (1), ss. 51-89. ISSN 1730-1599.

Light, R., Campbell B. (2007). Prisoners' Families: Still Forgotten Victims? Journal of Social Welfare and Family Law 28 (3-4), pp. 297-308. ISSN 0964-9069.

Machel, H. (2014). Rodzina skazanego jako wspótuczestnik jego resocjalizacji penitencjarnej, readaptacji i reintegracji społecznej. Resocjalizacja Polska 7, ss. 45-57. ISSN 2081-3767.

Mills, A., Cood, H. (2008). Prisoners' families and offender management: Mobilizing social capital. Probation Journal 55 (1), pp. 9-24. ISSN 0264-5505.

Nowak, B.M. (2011). Rodzina $w$ kryzysie złożonym: kontekst resocjalizacyjny. Resocjalizacja Polska 2, ss. 159-169. ISSN 2081-3767.

Oldrup, H., Frederiksen, S. (2018). Are the Children of Prisoners Socially Excluded? A Child-Centred Perspective. in: R. Condry, P.S. Smith (red.), Prisons, Punishment, and the Family. Towards a New Sociology in Punishment? (pp. 102-116). Oxford: Oxford University Press. ISBN 9780198810087.

Otwinowski, W. (2010). Kryzys i sytuacja kryzysowa. Przegląd Naukowo-Metodyczny. Edukacja dla Bezpieczeństwa 2, ss. 83-89. ISSN 1899-3524.

Paszkiewicz, A. (2017). Stygmatyzacja społeczna osób odbywających karę pozbawienia wolności - zarys problematyki, Przegląd Więziennictwa Polskiego 97. ss. 55-77. ISSN 1230-4433.

Pindel, E. (2011). Podtrzymywanie więzi rodzinnych $w$ warunkach izolacji. Probacja 1, ss. 92-104. ISSN 1689-6122.

Rozporządzenie Ministra Sprawiedliwości z dnia 13 czerwca 2016 r. w sprawie sposobu i trybu wykonywania czynności przez kuratorów sądowych w sprawach karnych wykonawczych. Dz.U.2016.969.

Rozporządzenie Ministra Sprawiedliwości z dnia 13 września 2017 r. w sprawie Funduszu Pomocy Pokrzywdzonym oraz Pomocy Postpenitencjarnej - Funduszu Sprawiedliwości. Dz.U.2019.683. 
Szczepanik, R., Miszewski, K. (2016). Wpływ długoterminowego uwięzienia na rodziny więźniów - stan wiedzy i zaniedbane kierunki badań. Profilaktyka Społeczna i Resocjalizacja 30, ss. 53-95. ISSN 2300-3952.

Szymanowska, A. (2003). Więzienie i co dalej. Warszawa: Wydawnictwo Akademickie „Żak”. ISBN 8389501058.

Ustawa z dnia 6 czerwca 1997 r. Kodeks karny wykonawczy. Dz.U.2020.523, tekst jednolity.

Ustawa z dnia 12 marca 2004 r. o pomocy społecznej. Dz.U.2019.1507, tekst jednolity.

Włodarczyk, E. (2011). Zdarzenie losowe i sytuacja kryzysowa. Czyli o tym, że niekiedy sam czas to za mało, by uleczyć rany. w: E. Włodarczyk, I. Cytlak (red.), Człowiek wobec krytycznych sytuacji życiowych. Z teorii i praktyki pracy socjalnej (ss. 311-330). Poznań: Wydawnictwo Naukowe UAM. ISBN 9788323223290.

Witkowska-Paleń, A. (2015). Programy wspierajace proces readaptacji społecznej skazanych $w$ zakładach karnych (wybrane przykłady). Journal of Modren Science 25(2), ss. 177-194. ISSN 1734-2031.

Wolińska, P. (2016). Znaczenie instytucji rodziny w życiu osób odbywających kare pozbawienia wolności w świetle stanu badań socjologicznych. Rozprawy Społeczne 10 (2), ss. 62-68. ISSN 2081-6081.

http://probacja.org/opieka-postpenitencjarna-i-wsparcie-dla-rodzin-osadzonych/ (dostęp: 11.08.2020).

http://probacja.org/2018-not-my-crime-still-my-sentence/ (dostęp: 11.08.2020).

https://www.pomoc-potrzebujacym.pl/index.php/pomoc-i-formy-wsparcia/dlarodzin-osob-osadzonych (dostęp: 30.07.2020).

https://www.fundacjaslawek.org/wsparcie-dla-rodzin (dostęp: 30.07.2020). 